\title{
Evaluation of Implementation of Public Elementary School Regrouping Policy in South Jakarta Region
}

\author{
Aryono Fajar Harianto*, Nurhattati Fuad, \& Sugiarto \\ Universitas Negeri Jakarta, Jl. Rawamangun Muka, RT.11/RW.14, Rawamangun, Pulo Gadung, Jakarta Timur, DKI \\ Jakarta, Indonesia 13220, Telp/fax: (021) 4898486 \\ E-mail: 1 aryono.fh22@gmail.com
}

How to Cite : Harianto, A., F. (2020). Evaluation of Implementation of Public Elementary School Regrouping Policy in South Jakarta Region. International Journal for Educational and Vocational Studies, 2 (4), 401-407. DOI: https://doi.org/10.29103/ijevs.v2i4.2552

\begin{abstract}
ARTICLE HISTORY
Received: 5 January 2020

Revised: 13 February 2020

Accepted: 22 March 2020

KEYWORDS

Regrouping Policy;

School Management;

Effective;

Efficient;

\section{ABSTRACT}

This study aims to obtain factual information regarding the implementation of the policy of merging public elementary schools in the South Jakarta region which consists of SDN Rawajati 03, SDN Pondok Pinang 10, and SDN Pejaten Timur 11. The method used in this study is evaluative with data collection techniques using interviews, observation, and documentation. Subjects in the study are the Principal, Teachers, and School Operators. The research findings show that the school incorporation policy is very precisely implemented which is seen from three perspectives of school managers who are research subjects. Based on the principal's perspective, it is known that the school incorporation policy has an impact on school management that is more effective and efficient so that education can run smoothly. The school incorporation policy also makes teachers work together and discuss related learning strategies so that students become more effective in learning and teaching activities. Different results were found from the perspective of school operators, namely the implementation of the school merger policy resulting in the increasing workload of school operators.
\end{abstract}

This is an open access article under the CC-BY-SA license.

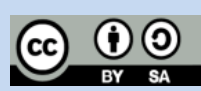

\section{INTRODUCTION}

Improving the quality of basic education has become a necessity in society and must be met by the government. Schools as formal educational service institutions are expected to be a place to improve the quality of human resources. The policy of merging schools is one of the government's efforts to meet the needs of the community in improving the quality of basic education, especially in elementary schools. The implementation of the school merger policy has been strengthened by Law Number 25 of 2000 concerning the National Development Program (Propenas) of 2000-2004 which explains that "one of the main activities in seeking an equal distribution of basic education is to carry out revitalization and incorporation of schools, especially primary schools, so that achieve efficiency and effectiveness of schools supported by adequate facilities."

The Provincial Government (Pemprov) of the Jakarta Special Capital Region has implemented a school merging policy. The law that underlies the policy of merging schools in DKI Jakarta Province is contained in Governor Regulation No. 105/2012 concerning Procedures for Establishing, Merging and Closing Educational Institutions. Article 20 paragraphs 1 and 2 explain that
"(1) Merger of educational institutions is a merging or merging of two or more similar educational institutions into one educational institution. (2) Educational institutions resulting from merging or merging as referred to in paragraph (1), shall become new educational institutions ". One area in DKI Jakarta Province that is implementing the merging of elementary schools in South Jakarta.

Education policies that are planned carefully can produce quality education. Gün \& Baskan (2014) explains that education as a process of deliberate change in improving individual behavior. One of the education policies implemented by the DKI Jakarta Provincial Government is the merger of elementary schools. Merger is a combination of two or more institutions that submit legal identity independently for a new shared identity in one management (Azziz, Hentschke, Jacobs, \& Ladd, 2017). The policy of merging elementary schools in DKI Jakarta Province especially South Jakarta Region has been carried out since 2013. In Table 2 it is explained that the merging of schools in the South Jakarta Region consists of two, three, and four schools into one school in one management led by one head school. 
Table 1. List of Public Elementary Schools in One Unit

\begin{tabular}{|c|c|c|c|c|}
\hline No. & District & No. & School Name Before Merge & Address \\
\hline \multirow{4}{*}{1} & \multirow{4}{*}{ Pasar Minggu } & 1 & SDN Pejaten Timur 11 Pagi & \multirow{4}{*}{ Jalan Pagujaten RT 016/06 } \\
\hline & & 2 & SDN Pejaten Timur 12 Petang & \\
\hline & & 3 & SDN Pejaten Timur 13 Pagi & \\
\hline & & 4 & SDN Pejaten Timur 14 Petang & \\
\hline \multirow{3}{*}{2} & \multirow{3}{*}{ Kebayoran Lama } & 1 & SDN Pondok Pinang 10 Pagi & \multirow{3}{*}{ Jalan Raya Pasar Jumat Komp. AU } \\
\hline & & 2 & SDN Pondok Pinang 11 Petang & \\
\hline & & 3 & SDN Pondok Pinang 12 Pagi & \\
\hline \multirow{2}{*}{3} & \multirow{2}{*}{ Pancoran } & 1 & SDN Rawajati 03 Pagi & \multirow{2}{*}{ Jalan Komp. ZEN I TNI AD VII } \\
\hline & & 2 & SDN Rawajati 04 Petang & \\
\hline
\end{tabular}

Source: Governor Decree Document Number 1929 of 2013

The purpose of the merger policy in DKI Jakarta Province is also explained in Article 21 which states that "the merger of educational institutions as referred to in Article 20 in the context of the efficiency and effectiveness of the administration of education". The efficiency and effectiveness of the administration of education can be done by combining two or more schools in one building unit under the same management. This is illustrated in Table 1 that in Pasar Minggu, Kebayoran Lama and Pancoran sub districts have two, three and four different schools in one building unit. Of course, every school principal has different policies so that school management becomes less efficient and effective. For the sake of achieving an effective and efficient education, the DKI Jakarta Provincial Government has made a policy to merge the schools into one school led by one school principal in the same school building

The concept of policy according to Diercks, Larsen, \& Steward (2018) as a framework of an idea that is a solution to a problem that should be addressed. Policies must be placed in a rational context so that the policy to be made has clear ideas and goals and can be an appropriate solution under existing problems. The policy of merging schools carried out by the DKI Jakarta
Provincial Government as one of the solutions to create effective and efficient education. The principle of effectiveness and efficiency in the delivery of education is what drives the DKI Jakarta Provincial Government to formulate a policy on combining elementary schools. This is in line with the statement of Yirci \& Karakose (2010) which explains that policies are certain principles that form a plan of activities to be carried out and are a decision that must be taken

Education policies that are planned carefully can produce quality education. Gün \& Baskan (2014) explains that education as a process of deliberate change in improving individual behavior. One of the education policies implemented by the DKI Jakarta Provincial Government is the merger of elementary schools. Merger is a combination of two or more institutions that submit legal identity independently for a new shared identity in one management (Azziz, Hentschke, Jacobs, \& Ladd, 2017). The policy of merging elementary schools in DKI Jakarta Province especially South Jakarta Region has been carried out since 2013. In Table 2 it is explained that the merging of schools in the South Jakarta Region consists of two, three, and four schools into one school in one management led by one head school.

Table 2. List of Primary Schools Before and After Merging

\begin{tabular}{|c|c|c|c|c|}
\hline No. & District & No. & School Names Before Merging & School Names After Merging \\
\hline \multirow{4}{*}{1} & \multirow{4}{*}{ Pasar Minggu } & 1 & SDN Pejaten Timur 11 Pagi & \multirow{4}{*}{ SDN Pejaten Timur 11 Pagi } \\
\hline & & 2 & SDN Pejaten Timur 12 Petang & \\
\hline & & 3 & SDN Pejaten Timur 13 Pagi & \\
\hline & & 4 & SDN Pejaten Timur 14 Petang & \\
\hline \multirow{3}{*}{2} & \multirow{3}{*}{ Kebayoran Lama } & 1 & SDN Pondok Pinang 10 Pagi & \multirow{3}{*}{ SDN Pondok Pinang $10 \mathrm{Pag}$} \\
\hline & & 2 & SDN Pondok Pinang 11 Petang & \\
\hline & & 3 & SDN Pondok Pinang 12 Pagi & \\
\hline \multirow{2}{*}{3} & \multirow{2}{*}{ Pancoran } & 1 & SDN Rawajati 03 Pagi & \multirow{2}{*}{ SDN Rawajati 03 Pagi } \\
\hline & & 2 & SDN Rawajati 04 Petang & \\
\hline
\end{tabular}

Source: Governor Decree Document Number 1929 of 2013 
The incorporation policy in DKI Jakarta Province is also in line with research of the Pennsylavnia School Boards Association (2009) which explains that the merger policy in school terminology implies the merging of two or more schools intending to eliminate administrative groups and multiple programs. According to Cai, Chen, \& Zhu (2017) the merging of schools is a policy that eliminates some elementary schools so that students are grouped in centralized schools. The policy aims to merge schools for the effectiveness and efficiency of education and to improve the quality of basic education.

Liu, Zhang, Luo, Rozelle, \& Loyalka (2010) explain that the policy of merging schools is a step taken by the government to close small schools in villages and combine them with larger schools in the city center. The overall goal of the merger program is to use more optimal educational resources and improve the quality of primary school education for all students. Naicker \& Mkhabele (2019) also stated that the purpose of merging schools is to increase the effective use of resources to improve the quality of education. Fulfilling the completeness of facilities to support specific learning programs is also one of the objectives of the merging of schools. Mo, Yi, Zhang, Shi, Rozelle, \& Medina (2012) empirically explain that the school merging program has been successful because a centralized school has better teachers, facilities and curriculum.

Evaluation is an inseparable step in every policy that has been made. A broad and deep understanding of the evaluation concept will make the evaluation stage run well and produce appropriate advice or recommendations. Suggestions or recommendations generated through the evaluation phase can be used as a basis for improving the implementation of policies that are running or that have been implemented. Evaluation is a structured process that creates and synthesizes information about certain policies (McDavid, Huse, \& Hawthorn, 2019). Evaluation is very helpful for policymakers in describing or assessing whether or not a set of policy goals have been achieved.

Tochot, Junpeng, \& Makmee (2012) explain that evaluation helps stakeholders to find out what works and what doesn't. Evaluations can also be carried out to analyze data and disseminate results and ensure that evaluations are beneficial for policymakers. The evaluation carried out is of course to assess the extent to which the policies that have been made can solve existing problems or can provide benefits to individuals or groups who carry out these policies.

Dunn (2017) also explains that evaluation methods can be used to generate knowledge about the value or usefulness of the results of the policies implemented. The results of the policy evaluation are a reference for policymakers to make further decisions on the policies that have been implemented. The merger policy in South Jakarta has been carried out since 2013, SDN Rawajati 03 Pagi, SDN Pondok Pinang 10 Pagi, and SDN Pejaten Timur 11 Pagi are schools that first ran the merging policy. An evaluation of the three schools must be carried out, in order to obtain factual information about the results of the implementation of the school incorporation policy.

\section{METHODS}

The method used in this study is evaluative. This evaluative study uses qualitative and quantitative data approaches. The subjects of the study were the Principal, Teachers, and School Operators at Rawajati 03 Morning Elementary School, Pondok Pinang 10 Morning Elementary School, and Pejaten Timur 11 Morning Elementary School listed in Governor Decree No. 1929 of 2013. Data collection techniques used were interviews, observation, and documentation. Research data analysis techniques refer to the concept of Yin (2011) which consists of five phases, namely: (1) data compilation, (2) data disassembly, (3) collecting data again, (4) data interpretation, and (5) drawing conclusions.

\section{RESULTS AND DISCUSSION}

\subsection{Results}

The implementation of the policy of merging elementary schools since 2013 in the South Jakarta Region, particularly SD Negeri Rawajati 03 Pagi, SD Negeri Pondok Pinang 10 Pagi, and SD Negeri Pejaten Timur 11 Pagi, in general, made education administration better. The school management has become more effective and efficient because principals can manage schools more flexibly and school-based management is easier to implement. The incorporation policy also makes teachers who were previously in each school to join a school and have the same teacher room. This has a positive impact because it makes it easy for teachers to cooperate and discuss learning activities and strategies. The incorporation policy also makes school facilities and infrastructure more complete and teachers can more freely use the facilities and infrastructure available in schools. Different results were found in the aspects of education personnel such as school operators, the implementation of school incorporation policies resulted in the increasing workload of school operators. This is due to the number of students combined not being matched by an increase in the number of school operators.

Table 3. Number of Students

\begin{tabular}{ccccc}
\hline No. & Class & $\begin{array}{c}\text { SDN Rawajati } \\
\text { 03 Pagi }\end{array}$ & $\begin{array}{c}\text { SDN Pondok } \\
\text { Pinang 10 Pagi }\end{array}$ & $\begin{array}{c}\text { SDN Pejaten } \\
\text { Timur 11 Pagi }\end{array}$ \\
\hline 1 & I & 63 & 64 & 126 \\
\hline 2 & II & 63 & 97 & 86 \\
\hline 3 & III & 94 & 108 & 95 \\
\hline 4 & IV & 93 & 92 & 99 \\
\hline 5 & V & 63 & 63 & 95 \\
\hline 6 & VI & 34 & 82 & 588 \\
\hline
\end{tabular}


Source: School Documents

Another finding in this study is the number of students who differ between the merging of two, three, and four schools. Table 3 shows that East Pejaten Elementary School 11, which is a merger of four schools, has the highest number of students, 588 students. SD Negeri Pondok Pinang 10 from the merging of three schools has 506 students. SD Negeri Rawajati 03 Morning from the merger of two schools has the smallest number of students, ie 410 . This explains that the results of the merging of the four schools have the highest number of students.

Table 4. Number of Study Groups

\begin{tabular}{ccccc}
\hline No. & Class & $\begin{array}{c}\text { SDN Rawajati } \\
\text { 03 Pagi }\end{array}$ & $\begin{array}{c}\text { SDN Pondok } \\
\text { Pinang 10 Pagi }\end{array}$ & $\begin{array}{c}\text { SDN Pejaten } \\
\text { Timur 11 Pagi }\end{array}$ \\
\hline 1 & I & 2 & 2 & 4 \\
\hline 2 & II & 2 & 3 & 4 \\
\hline 3 & III & 3 & 4 & 3 \\
\hline 4 & IV & 3 & 3 & 3 \\
\hline 5 & V & 2 & 2 & 21 \\
\hline 6 & VI & 1 & 3 & 37 \\
\hline
\end{tabular}

Source: School Documents

The number of mergers in different schools will certainly have a different number of study groups. Based on table 4, Pejaten Timur 11 Public Elementary School originating from the merging of four schools has 21 study groups. Pondok Pinang 10 Public Elementary School from a merger of three schools has 17 study groups. SD Negeri Rawajati 03 Morning from the merging of two schools has 13 study groups. This shows that the merging of the four schools has the highest number of study groups.

Table 5. Availability of Educators and Education

\begin{tabular}{llccc} 
Personnel & & \\
No. & $\begin{array}{c}\text { Educator and } \\
\text { Education Personnel }\end{array}$ & $\begin{array}{c}\text { SDN } \\
\text { Rawajati } \\
\text { 03 Pagi }\end{array}$ & $\begin{array}{c}\text { Pondok } \\
\text { Pinang 10 } \\
\text { Pagi }\end{array}$ & $\begin{array}{c}\text { SDN } \\
\text { Pejaten } \\
\text { Timur 11 } \\
\text { Pagi }\end{array}$ \\
\hline 1 & Headmaster & 1 & 1 & 1 \\
\hline 2 & Classroom teacher & 13 & 17 & 21 \\
\hline 3 & Islamic Teachers & 1 & 3 & 3 \\
\hline 4 & $\begin{array}{l}\text { Catholic Religious } \\
\text { Teacher }\end{array}$ & 0 & 1 & 2 \\
\hline 5 & PJOK teacher & 2 & 1 & 2 \\
\hline 6 & Administrator & 1 & 1 & 2 \\
\hline 7 & Security & 19 & 26 & 31 \\
\hline & Total & & & 2 \\
\hline
\end{tabular}

Source: School Documents

The difference in the number of students in a school also makes educators and educators have different numbers. Table 5 shows the Pejaten Timur SDN 11 originating from the merging of four schools has 31 teaching and educational staff. SDN Pondok Pinang 10 from the merging of three schools has 26 educators and education staff. SDN Rawajati 03 Morning from the merging of two schools has 19 educators and educational staff.

\subsection{Discussion}

The aim of implementing the merger policy at Rawajati 03 Morning Elementary School, Pondok Pinang 10 Morning Elementary School and Pejaten Timur 11 Morning Elementary School is to make school management more effective and the school principal can better implement the school-based management system. This finding is consistent with the results of an earlier study revealed by Setiawati (2018) that the school merging program as a concept and strategy for basic education management has been able to realize more effective and efficient management of basic education. In addition, the merging policy carried out at the three elementary schools also had a positive impact on aspects of the learning process. The incorporation policy makes students who previously came from evening schools must participate in learning and teaching activities in the morning that were responded to by both students and parents. The interview results show that parents of students who previously came from evening school basically wanted their children to go to school in the morning. This is because the learning process carried out during the day makes it difficult for students to concentrate due to activities in the morning such as playing.

The incorporation policy also makes teachers have even more discussion partners. If previously the teacher only discussed with the teacher in the original school, then the incorporation policy made the peer teachers discuss become more. The teacher can have the same time and space when discussing. Before the merger, the teacher does not have the same time and space for discussion because there are teachers who teach in the morning and afternoon. School facilities and infrastructure have also become more complete with the school incorporation policy. This is in line with the findings of Mo et al. (2012) which empirically states that the merging program makes schools have better facilities so that teachers can be more innovative and effective in providing subject matter.

Based on the results of interviews with the Principal and Teacher, in general, the implementation of the merging policy in Rawajati 03 Morning Elementary School, Pondok Pinang 10 Morning Elementary School, and Pejaten Timur 11 Morning Elementary School also made the learning process more efficient and effective because no more students entered during the day and school facilities become more complete. However, if seen from the average number of students per group in each school. There are several schools that have a ratio between the number of students and study groups not ideal. This can be seen in Table 6 which illustrates the average number of students per study group in each school. 
Table 6. Average Number of Students per Study Group

\begin{tabular}{ccccc}
\hline No. & Class & $\begin{array}{c}\text { SDN Rawajati } \\
\text { 03 Pagi }\end{array}$ & $\begin{array}{c}\text { SDN Pondok } \\
\text { Pinang 10 } \\
\text { Pagi }\end{array}$ & $\begin{array}{c}\text { SDN Pejaten } \\
\text { Timur 11 Pagi }\end{array}$ \\
\hline 1 & I & 31.5 & 32.0 & 31.5 \\
\hline 2 & II & 31.5 & 32.3 & 21.5 \\
\hline 3 & III & 31.3 & 27.0 & 23.8 \\
\hline 4 & IV & 31.0 & 30.7 & 33.0 \\
\hline 5 & V & 31.5 & 31.5 & 29.0 \\
\hline 6 & VI & 34.0 & 27.3 & 31.7 \\
\hline & Average & 31.8 & 30.1 & 28.4 \\
\hline
\end{tabular}

Based on Table 6, Rawajati State Elementary School 03 in the morning had an average number of students per study group of 31.8. SD Negeri Pondok Pinang 10 in the morning has an average number of students per study group of 30.1. Pejaten Timur Elementary School 11 in the morning had an average number of students per study group of 28.4. While the Minister of Education and Culture Regulation No. 22 of 2016 concerning Process Standards explains that the maximum number of students per study group at the SD / MI level is 28 students. If referring to the Ministry of Education and Culture, only 11 East Jakarta Public Elementary School currently has an ideal student ratio and study group. The ratio of the number of students to the number of study groups at Pondok Pinang Public Elementary School 10 in the morning and Rawajati Public Elementary School 03 in the morning is not ideal because it exceeds the maximum limit, which is above 28 students.

The results of interviews with the Principal explained that one of the reasons was not ideally the ratio of the number of students per number of study groups at Pondok Pinang State Elementary School 10 am and Rawajati State Elementary School 03 morning was the high number of school enthusiasts, both from around and outside the school environment. Principals at Pondok Pinang Public Elementary School 10 in the morning and SD Negeri Rawajati 03 in the morning have actually reduced the number of study groups each new school year so that the ratio of the number of students per study group becomes ideal. However, because of the high level of community interest in the two schools, the principal must continue to accept students who want to go to school, thereby increasing the number of study groups.

Increasing the number of study groups also has an impact on the ideal ratio of the number of study groups and the number of classrooms. This happened because the merging policy implemented at Rawajati 03 Morning Elementary School, Pondok Pinang 10 Morning Elementary School, and Pejaten Timur 11 Morning Elementary School since 2013 did not build new buildings. The three schools have been implemented since the beginning of the merger policy and continue to use the old school building. This makes no increase in the number of classrooms in each of these schools so that the ratio between the number of study groups and the number of classrooms in Rawajati 03 Morning Elementary School and Pejaten Timur 11 Pagi Elementary School becomes unbalanced (Table 7).

Table 7. Number of Classes and Classrooms

\begin{tabular}{|c|c|c|c|c|}
\hline \multirow[b]{2}{*}{ No. } & \multirow[b]{2}{*}{ Schools } & \multicolumn{2}{|c|}{ Quantity } & \multirow{2}{*}{$\begin{array}{c}\text { Lack of } \\
\text { Classroom }\end{array}$} \\
\hline & & $\begin{array}{l}\text { Study } \\
\text { Group }\end{array}$ & $\begin{array}{l}\text { Class } \\
\text { Room }\end{array}$ & \\
\hline 1 & $\begin{array}{l}\text { SDN Rawajati } 03 \\
\text { Pagi }\end{array}$ & 13 & 10 & 3 \\
\hline 2 & $\begin{array}{l}\text { SDN Pondok Pinang } \\
10 \text { Pagi }\end{array}$ & 17 & 17 & 0 \\
\hline 3 & $\begin{array}{l}\text { SDN Pejaten Timur } \\
11 \text { Pagi }\end{array}$ & 21 & 15 & 6 \\
\hline
\end{tabular}

Source: School Documents

The ratio between the number of classes and classrooms is not ideal in Rawajati 03 Pagi Elementary School and Pejaten Timur 11 Morning Elementary School because there is no construction of new school buildings. The merging policy in the two schools is not balanced with sufficient classrooms so that the learning process is made parallel. The parallel learning process is carried out so that each student still gets the same quality of educational services. The parallel learning process is carried out in first, second, and third-grade classes while none of the fourth, fifth and sixth-grade classes are paralleled. The ratio between the number of classes and classrooms at Pondok Pinang 10 Pagi Elementary School remains ideal to date because the school building has three floors and sufficient classroom capacity.

Other findings when viewed from the aspect of education personnel, especially school operators, the incorporation policy makes the burden of school operator's increase because students from each school are combined into one. However, the merging of students was not accompanied by an increase in the number of school operators. Based on the results of the interviews, when the merger policy was implemented there were school operators who became teachers and some had retired. This has made the school operator's staff less. At present, the task of school operators is not only as student administration staff in schools, but school operators are also tasked to enter the principal data of educators, map the quality of school education, and enter grades into electronic report cards (e-report cards). Implementation of the merger policy that was not matched by the addition of school operator personnel increased the burden on school operators. This is in line with Pang's findings in the study of Liu et. al (2010) which states that the burden of administrative staff in schools combined becomes increased.

\section{CONCLUSION}

The implementation of the school incorporation policy in DKI Jakarta Province since 2013 has made the administration of education effective and efficient. School principals have become better at implementing 
school-based management systems. The teacher has more discussion partners, thus creating a comprehensive learning strategy. Students become more effective in receiving and understanding the subject matter delivered by the teacher. School facilities and infrastructure become more adequate and flexible to be used to make the learning process more creative and innovative.

The process of providing more effective education with the policy of merging schools is not accompanied by equal distribution of the workload of education personnel, especially school operators. Therefore, it is hoped that the DKI Jakarta Provincial Government, in this case, the Office of Education can increase the number of school operators. Besides, schools that have a ratio of the number of study groups and the number of classrooms that are not ideal should be a concern for the DKI Jakarta Provincial Government, so that students can receive optimal quality education services.

\section{Acknowledgment}

We thank the Principals, Teachers, and School Operators at Rawajati 03 Pagi Elementary School, Pondok Pinang 10 Morning Elementary School, and Pejaten Timur Negeri 11 Morning Elementary School for permission and information given in this study.

\section{REFERENCES}

Her Azziz, R., Hentschke, G. C., Parthenon-EY, E., Young, L. L. P., Jacobs, B. C., Jacobs, L. A., \& Ladd, H. (2017). Mergers in Higher Education: A proactive strategy to a better future?.

Cai, W., Chen, G., \& Zhu, F. (2017). Has the compulsory school merger program reduced the welfare of rural residents in China?. China Economic Review, 46, 123-141. doi:10.1016/j.chieco.2017.07.010

Diercks, G., Larsen, H., \& Steward, F. (2018). Transformative innovation policy: Addressing variety in an emerging policy paradigm. Research Policy. 880-894.

doi:10.1016/j.respol.2018.10.028

Dunn, W. N. (2017). Public policy analysis: an integrated approach. Routledge.

Gün, F., \& Baskan, G. A. (2014). New education system in Turkey (4+4+4): A critical outlook.

Procedia-Social and Behavioral Sciences, 131, 229-235. doi:10.1016/j.sbspro.2014.04.109

Liu, C., Zhang, L., Luo, R., Rozelle, S., \& Loyalka, P. (2010). The effect of primary school mergers on academic performance of students in rural China. International Journal of Educational Development, 30(6), 570-585.

doi:10.1016/j.ijedudev.2010.05.003

McDavid, J. C., Huse, I., \& Hawthorn, L. R. (2019). Program evaluation and performance measurement: An introduction to practice. Sage Publications.
Mo, D., Yi, H., Zhang, L., Shi, Y., Rozelle, S., \& Medina, A. (2012). Transfer paths and academic performance: The primary school merger program in china. International Journal of Educational Development, 32(3), 423-431. doi:10.1016/j.ijedudev.2011.11.001

Naicker, S. R., \& Mkhabele, N. N. (2019). Resistance to School Mergers by Traditional Leaders, Principals and Parents. Africa Education Review,115. doi:10.1080/18146627.2018.1534548

Pennsylvania School Boards Association. (2009). Merger/Consolidation of School Districts: Does it save money and improve student achievement. Rep. Mechanicsburg: Pennsylvania School Boards Association.

Peraturan Gubernur DKI Jakarta 2012 No. 105. Prosedur Pendirian, Penggabungan, dan Penutupan Lembaga Pendidikan. Jakarta.

Setiawati, T. (2018). Program Penggabungan Sekolah Dasar (SD) Dalam Meningkatkan Efektivitas dan Efisiensi Penyelenggaraan Pendidikan. MENDIDIK: Jurnal Kajian Pendidikan Dan Pengajaran, 4(1), 55-62.

Tochot, P., Junpeng, P., \& Makmee, P. (2012). Measurement Model of Evaluation Utilization: External Evaluation. Procedia - Social and Behavioral Sciences, 69, 1751-1756.

doi:10.1016/j.sbspro.2012.12.124

Undang-Undang RI 2000 No. 20. Program Pembangunan Nasional (Propenas) Tahun 2000-2004. Jakarta.

Yin, R. K. (2011). Qualitative research from start to finish. Guilford Publications.

Yirci, R., \& Karaköse, T. (2010). Democratic education policy and Turkish education system.

Procedia-Social and Behavioral Sciences, 9, 1330-1334.

doi:10.1016/j.sbspro.2010.12.329

Nawan, A. H., Permasih, \& Dewi, L. (2008). Panduan Pengembangan Bahan Ajar. Depdiknas Jakarta, $1-13$.

Retrievedfrom http://file.upi.edu/Direktori/FIP/JUR._KURIKULU M_DAN_TEK._PENDIDIKAN/194601291981012-P ERMASIH/PENGEMBANGAN_BAHAN_AJAR.pdf

Lee, W. W., \& Owens, D. L. (2012). Multimedia-Based Instructional Design. In Pfeiffer. https://doi.org/10.1007/s13398-014-0173-7.2

Rowntree, D. (1994). Preparing Materials for Open, Distance and Flexible Learning -. In British Journal of Educational Technology.

Setiawan, H., \& Jawapos.com. (2018). Sempat Dihapus, Mata Pelajaran TIK Kini Bernama Informatika.

Retrieved from

https://www.jawapos.com/nasional/pendidikan/01/09 /2018/sempat-dihapus-mata-pelajaran-tik-kini-bern ama-informatika/ website:

https://www.jawapos.com/nasional/pendidikan/01/09 /2018/sempat-dihapus-mata-pelajaran-tik-kini-bern ama-informatika/ 
Sugiyono. (2018). Metode Penelitian Kuantitatif,Kualitatif dan R\&D. In ke-26.

Wedan, M. (2016). Pengertian Pendidikan dan Tujuan Pendidikan Secara Umum.

Yaumi, M. (2018). Media dan Teknologi Pembelajaran. In Jakarta. 